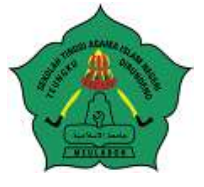

AT-TASYRI' Jurnal Ilmiah Prodi Muamalah

P-ISSN: 2085-2541, E-ISSN: 2715-7865

Volume 12, Nomor 1, Juni 2020

https://ejournal.staindirundeng.ac.id/index.php/Tasyri

\title{
ANALISIS PENGARUH JUMLAH PENDUDUK DAN PRODUK DOMESTIK REGIONAL BRUTO (PDRB) TERHADAP KEMISKINAN DI KABUPATEN NAGAN RAYA
}

\author{
Muliza \\ Dosen Syariah dan Ekonomi Islam, STAIN Teungku Dirundeng Meulaboh \\ muliza@staindirundeng.ac.id
}

\begin{abstract}
Abstrak
Penelitian ini bertujuan untuk mengetahui dan menganalisis pengaruh jumlah penduduk dan Produk Domestik Regional Bruto (PDRB) terhadap kemiskinan di Kabupaten Nagan Raya baik secara parsial maupun simultan selama kurun waktu tahun 2010 hingga 2019. Variabel dependen dalam penelitian ini adalah kemiskinan sedangkan variabel independennya adalah jumlah penduduk dan PDRB. Metode yang digunakan untuk mengetahui pengaruh dari variabel independent terhadap variabel dependen adalah dengan menggunakan analisis regresi linier berganda. Berdasarkan hasil penelitian dan dari hasil analisis data, maka dapat disimpulkan bahwa secara simultan variabel jumlah penduduk dan PDRB berpengaruh siginifikan terhadap variabel kemiskinan hal ini dapat dilihat dari nilai $\mathrm{F}_{\text {hitung }}$ lebih besar dari $\mathrm{F}_{\text {tabel. }}$. Dari hasil nilai koefisien determininasi diperolah bawah pengaruh variable jumlah penduduk dan PDRB sebesar $87,9 \%$ dan sisanya $12,1 \%$ di pengaruhi oleh variable lain di luar model penelitian ini, namun secara simultan variabel jumlah penduduk dan PDRB tidak memberikan hasil yang signifikan terhdap kemiskinan di Kabupaten Nagan Raya hal ini dapat dilihat dari nilai $\mathrm{T}_{\text {hitung }}$ kedua variable bebeas tersebut lebih kecil dari nilai $\mathrm{T}_{\text {tabel. }}$.
\end{abstract}

Kata kunci : Jumlah penduduk, PDRB, kemiskinan.

\begin{abstract}
Product Domestic Regional Bruto (PDRB) on poverty in Nagan Raya Regency both partially and simultaneously during the period 2010 to 2019. The dependent variable in this study is the independent variable is the population and PDRB. The method used to study the effect of the independent variables on the dependent variable uses multiple linear regression analysis. Based on the results of the study and from the results of data analysis, it can be concluded that the simultaneous variable of population and PDRB is significant to the poverty variable, it can be seen from the F-count value greater than F-table. From the results of the determination coefficient value is calculated under the variable influence of population and PDRB of $87.9 \%$ and the remaining $12.1 \%$ is influenced by other variables outside this research model, but simultaneously the variable number of population and PDRB does not provide significant results on welfare in Nagan Raya Regency can be seen from the value of Thitung the second variable is smaller than the value of $\mathrm{T}$ table.
\end{abstract}

Keywords : Total population, PDRB, poverty 


\section{A. PENDAhuluan}

Keberhasilan suatu negara untuk mencapai pembangunan yang berkelanjutan salah satunya adalah dengan kemampuan pemerintah untuk meminimalisir jumlah pendudukan miskin di negara tersebut. Kemiskinan merupakan suatu problematika kemanusiaan yang hingga saat ini masih menjadi suatu permasalahan dibelahan bumi manapun. Istilah tentang kemiskinan muncul ketika seseorang atau sekelompok orang tidak mampu untuk mencukupi tingkat kemakmuran ekonomi yang dianggap sebagai kebutuhan minimal dari standar hindup tertentu. Menurut World Bank salah satu sebab kemiskinan adalah karena kurangnya pendapatan dan asset (lack of income and assets) untuk memenuhi kebutuhan dasar seperti makanan, pakaian, perumahan dan tingkat Kesehatan dan Pendidikan yang dapat diterima (acceptable). ${ }^{1}$

Upaya pengentasan kemiskinan baik pemerintah pusat maupun daerah telah melaksanakkan berbagai kebijakan dan program-program penanggulangan kemiskinan, namun hal ini masih jauh dari optimal. Masih ada kebijakan dan program yang dilaksanakan belum menapakkan hasil yang optimal. Namun usaha pemerintah dalam penangggulangan kemiskian sangatlah serius bahkan merupakan salah satu program prioritas setiap daerah, termasuk bagi pemerintah Kabupaten Nagan Raya.
Tabel I

Tingkat Kemiskinan dan Garis Kemiskinan Kabupaten Nagan Raya Tahun 2010-2019

\begin{tabular}{|c|c|c|}
\hline Tahun & $\begin{array}{c}\text { Kemiskinan } \\
\text { (Jiwa) }\end{array}$ & $\begin{array}{c}\text { Garis } \\
\text { Kemiskinan (Rp) }\end{array}$ \\
\hline 2010 & 33,40 & 320.490 \\
\hline 2011 & 33,57 & 346.254 \\
\hline 2012 & 32,72 & 349.550 \\
\hline 2013 & 32,70 & 353.231 \\
\hline 2014 & 31,90 & 356.221 \\
\hline 2015 & 31,32 & 361.359 \\
\hline 2016 & 30,31 & 374.236 \\
\hline 2017 & 31,06 & 400.811 \\
\hline 2018 & 31,06 & 426.827 \\
\hline 2019 & 29,93 & 446.144 \\
\hline
\end{tabular}

Sumber : BPS Kabupaten Nagan Raya 2020

Meskipun tingkat kemiskinan di Kabupaten Nagan Raya masih tergolong relative tinggi, namum setiap tahunnya angka kemiskinan terus mengalami penurunan, ini mengidikasikan bahwa upaya pemerintah dalam penanggulangan angka kemiskinan telah berjalan dengan baik meskipun masih belum sepenuhnya optimal.

Secara umum, tingkat kemiskinan disuatu daerah seperti halnya dari segi jumlah penduduk. Pertumbuhan penduduk merupakan keseimbangan yang dinamis antara kekuatan-kekuatan yang menambah dan kekuatan-kekuatan yang mengurangi jumlah penduduk. Secara terus menerus penduduk akan dipengaruhi oleh jumlah bayi yang lahir (menambah jumlah penduduk), tetapi secara bersamaan pula akan dikurangi oleh jumlah kematian yang terjadi pada semua golongan umur. Secara tidak langsung, pertumbuhan penduduk dapat mempengaruhi pertumbuhan ekonomi, hal ini dapat dilihat dari nilai PDRB, semakin banyak pennduduk maka semakin banyak pula jumlah tenaga kerja yang bisa digunakan. Akan tetapi

\footnotetext{
${ }^{1}$ Word Bank 2004 dalam Reza Atta Biurobbi, Faktor-faktor yang memepengaruhi kemiskinan di Kecamatan Jekulo dan Mojebo Kabupaten Kudus, 2013.
} 
apabila hal ini tidak diikuti oleh kemampuan SDM yang baik dan kurangnya kecukupan lapangan kerja, maka pertumbuhan penduduk juga akan menjadi ancaman bagi suatu daerah yang bisa meningkatkan jumlah pengangguran dan berakibat terhadap peningkatan tingkat kemiskinan.

Selain itu, keberhasilan suatu daerah dalam melakukan pengurangan tingkat kemiskinan juga bisa dilihat dari segi pertumbuhan ekonomi, hal ini dapat terlihat dari Pendapatan Daerah Regional Bruto (PDRB). Tingkat PDRB yang tinggi diharapkan dapat menjadi suatu modal bagi daerah dalam melakukan pengentasan kemiskinan. Berikut data Laju pertumbuhan PDRB Kabupaten Nagan Raya selama kurun waktu 2010-2019:

Tabel II

PDRB Atas dasar harga konstan 2010 Kabupaten Nagan Raya Tahun 2010-2020

\begin{tabular}{|c|c|}
\hline Tahun & PDRB (Juta Rupiah) \\
\hline 2010 & 4.573 .878 \\
\hline 2011 & 4.693 .588 \\
\hline 2012 & 4.867 .307 \\
\hline 2013 & 5.032 .698 \\
\hline 2014 & 5.204 .812 \\
\hline 2015 & 5.422 .070 \\
\hline 2016 & 5.641 .779 \\
\hline 2017 & 5.867 .771 \\
\hline 2018 & 6.119 .920 \\
\hline 2019 & 6.486 .710 \\
\hline
\end{tabular}

Sumber : BPS Kabupaten Nagan Raya 2020

Dari data pada tabel 2 dapat dilihat angka PDRB di Kabupaten Nagan Raya dalam jangka waktu 2010-2019 yang di mana selama kurun waktu 10 tahun tersebut angka PDRB Kabupaten Nagan Raya tersu mengalami kenaikan, sector tersbesar yang berpengaruh terhadap penerimaan PDRB di
Kabupaten Nagan Raya adalah di sector pertanian dan perkebunan, hal ini mengindikasikan bahawa pertanian merupakan sector unggulan yang harus diperhatikan oleh pemerintah untuk peningkatan PDRB di tahun-tahun berikutnya. Pertumbuhan PDRB meruakan cerimanan dari pertumbuhan Ekonomi. Setiap negara akan berusaha keras untuk mencapai pertumbuhan ekonomi yang optimal dan menurunkan angka kemiskinan. Di banyak negara di dunia syarat utama bagi terciptanya penurunan kemiskinan adalah pertumbuhan ekonomi. Namun, kondisi di negara-negara berkembang termasuk Indonesia pertumbuhan ekonomi yang dicapai ternyata juga diiringi dengan munculnya permasalahan meningkatnya jumlah penduduk yang hidup dibawah garis kemiskinan. Besarnya kemiskinan dapat diukur dengan atau tanpa mengacu kepada garis kemiskinan. Konsep yang mengacu kepada garis kemiskinan disebut kemiskinan relative, sedangkan konsep pengukurannya tidak didasarkan pada garis kemiskinan disebut kemiskinan absolute. Kemiskinan relative adalah suatu ukuran mengenai kesenjangan dalam distribusi pendapatan, yang biasanya dapat didefinisikan didalam kaitannya dengan tingkat rata-rata dari distribusi yang dimaksud².

Berdasarkan uraian permasalahan tersebut maka, penelitian ini bertujuan untuk melihat pengaruh dari jumlah penduduk dan Produk Domestik Regional Bruto (PDRB) terhadap tingkat kemiskinan di Kabupaten Nagan Raya pada tahun 2010-2020. hal. 84 .

${ }^{2}$ Tulus Tambunnan, Perekonomian Indonesia Beberapa Masalah Penting (Jakarta: Ghalia Indonesia, 2003) 


\section{B. KAJIAN PUSTAKA}

\section{Kependudukan}

Menurut Penduduk adalah semua orang yang berdomisili di wilayah geografis Republik Indonesia selama 6 bulan atau lebih dan atau mereka yang berdomisili kurang dari 6 bulan tetapi bertujuan untuk menetap. ${ }^{3}$

Penduduk merupakan unsur penting dalam kegiatan ekonomi serta usaha membangun suatu perekonomian karena penduduk menyediakan tenaga kerja, tenaga ahli, pimpinan perusahaan tenaga kerja usahawan dalam menciptakan kegiatan ekonomi ${ }^{4}$.

Teori konfusius membahas hubungan antara jumlah penduduk dan tingkat kesejahteraan masyarakat. Menurutnya jumlah penduduk yang terlampau besar akan menekan standar hidup masyarakat, terutama kalau jumlah penduduk dikaitkan dengan luas tanah atau lahan pertanian yang tersedia untuk memenuhi kebutuhan penduduk. Konfusius menganggap ada suatu proposi yang ideal antara luas tanah dan jumlah penduduk. Sebagai pemecahan masalah kelebihan penduduk, ia menganjurkan agar pemerintah memindahkan penduduk ke daerah yang masih kekurangan penduduk. ${ }^{5}$

\section{Produk Domestik Regional Bruto (PDRB)}

Produk Domestik Regional Bruto (PDRB) merupakan jumlah nilai tambah yang dihasilkan untuk seluruh wilayah usaha dan jasa dalam suatu wilayah, menerapkan jumlah seluruh nilai barang dan jasa akhir yang dihasilkan seluruh unit ekonomi. PDRB sendiri dapat diartikan sebagai jumlah nilai tambah yang dihasilkan oleh seluruh unit usaha atau merupakan jumlah seluruh nilai barang dan jasa oleh seluruh unit ekonomi di suatu wilayah. ${ }^{6}$

Untuk mengetahui kondisi suatu perekonomian dalam suatu daerah, indikator penting yang digunakan adalah PDRB, dapat menggunakan atas dasar harga konstan maupun harga berlaku. Produk Domestik Regional Bruto (PDRB) adalah nilai tambah yang mampu diciptakan dari berbagai aktivitas ekonomi dalam suatu wilayah. Istilah PDRB merupakan gabungan dari empat kata. Pertama adalah produk yang berarti seluruh nilai produksi baik barang maupun jasa. Kedua adalah domestik yang berarti perhitungan nilai produksi yang dihasilkan hanya oleh faktor-faktor produksi yang berada dalam wilayah domestik tanpa melihat apakah faktor produksi tersebut dikuasai oleh penduduk atau bukan. Ketiga adalah regional, artinya perhitungan nilai produksi yang dihasilkan hanya oleh penduduk tanpa memperhatikan apakah faktor produksi yang digunakan berada dalam wilayah domestik atau bukan. Terakhir adalah bruto yang bermakna perhitungan nilai produksi kotor karena masih mengandung biaya penyusutan. ${ }^{7}$

\section{Kemiskinan}

Kemiskinan merupakan kondisi absolut atau relatif yang menyebabkan seseorang atau kelompok masyarakat dalam suatu wilayah tidak mempunyai kemampuan untuk mencukupi kebutuhan dasarnya sesuai dengan tata nilai atau norma tertentu yang berlaku di

\footnotetext{
${ }^{3}$ https://naganrayakab.bps.go.id/subject/12/kependudukan.html\#subjekViewTab1, diakses tanggal 25 April 2020

${ }^{4}$ Sadono Sukirno, Pengantar Teori Ekonomi Makro, (Jakarta: Predana Media Group, 2005) hal. 142.

${ }^{5}$ Adioetomo, dkk. Dasar-dasar Demografi, (Jakarta: Salemba Empat, 2010) hal.15.

${ }^{6}$ https://naganrayakab.bps.go.id/subject/52/produk-domestik-regional-bruto.html\#subjekViewTab1, diakses tanggal 25 April 2020.

${ }^{7}$ Saberan, Produk Domestik regional Bruto (Jakarta: Rajawali, 2002) hal. 5.
} 
dalam masyarakat karena sebab-sebab natura, kultural, atau struktural. Dengan kata lain, seseorang dikatakan miskin jika dan hanya jika tingkat pendapatannya tidak memungkinkan orang tersebut untuk menaati tata nilai dan norma dalam masyarakatnya. ${ }^{8}$

Kemiskinan merupakan kondisi ketika seseorang atau sekelompok orang tidak mampu memenuhi hak-hak dasarnya untuk mempertahankan dan mengembangkan kehidupan yang bermartabat. Hak-hak dasar tersebut antara lain: terpenuhinya kebutuhan pangan, kesehatan, pendidikan, pekerjaan, perumahan, air bersih, pertanahan, sumberdaya alam lingkungan hidup, rasa aman dari perlakuan atau ancaman tindak kekerasan dan hak untuk berpartisipasi dalam kehidupan sosial-politik ${ }^{9}$.

\section{DATA DAN METODOLOGI}

\section{Ruang Lingkup Penelitian}

Penelitiaan ini dilakukan di Kabupaten Nagan Raya dengan data penelitian yang digunakan yaitu data time series dari tahun 2010-2019. Penelitian ini difokuskan untuk melihat pengaruh dari jumlah penduduk dan pendapatan domestik regional daerah (PDRB) terhadap Kemiskinan.

\section{Sumber dan Jenis Data}

Jenis data yang digunakan dalam penelitian ini adalah data sekunder yang meliputi Jumlah Penduduk, PDRB, dan jumlah penduduk miskin di Kabupaten Nagan Raya dari tahun 2010-2019. Data tersebut diperoleh dari Badan Pusat Statistik (BPS) Kabupaten Nagan Raya.

\section{Model Analisis Data}

Metode penelitian yang digunakan dalam penelitian ini adalah dengan menggunakan metode yang bersifat kuantitatif. Model yang digunakan untuk melihat seberapa besar dan bagaimana pengaruh dari jumlah penduduk dan PDRB terhadap tingkat Kemiskinan di Kabupaten Nagan Raya adalah dengan menggunakan model regresi linier berganda. Adapun formulasi koefisien regresi berganda yaitu :

$\operatorname{LnY}=\mathbf{a}+\mathrm{B}_{1} \operatorname{LnX} X_{1}+B_{2} \operatorname{LnX} X_{2}+e$

Dimana :

Y : Jumlah Penduduk Miskin

a : Konstanta

b : Koefisien regresi

$\mathrm{X}_{1} \quad$ : Jumlah Penduduk

$\mathrm{X}_{2} \quad$ : PDRB

e : Error terms

\section{HASIL DAN PEMBAHASAN}

1. Kondisi Perekonomian Kabupaten Nagan Raya

Kabupaten Nagan Raya merupakan salah satu kabupaten yang berada di Barat Selatan Provinsi Aceh. Sektor pertanian merupakan salah satu sektor unggulan penyumbang PDRB terbesar di Kabupaten Nagan Raya, Berikut ini dapat dilihat tingkat pertumbuhan ekonomi di Kabupaten Nagan Raya.

\footnotetext{
${ }^{8}$ Nugroho dalam Novri Silastri, Pengaruh Jumlah Penduduk dan Pendapatan Domestik Regional bruto (PDRB) Terhadap Kemiskinan di Kabupaten Kuatan Singingi, 2017.

${ }^{9}$ Bapenas, Strategi Nasional Penanggulangan Kemiskinan (Jakarta: Bappenas, 2004).
} 


\section{Gambar 1}

Laju Pertumbuhan Ekonomi Kabupaten Nagan Raya Tahun 2013-2019

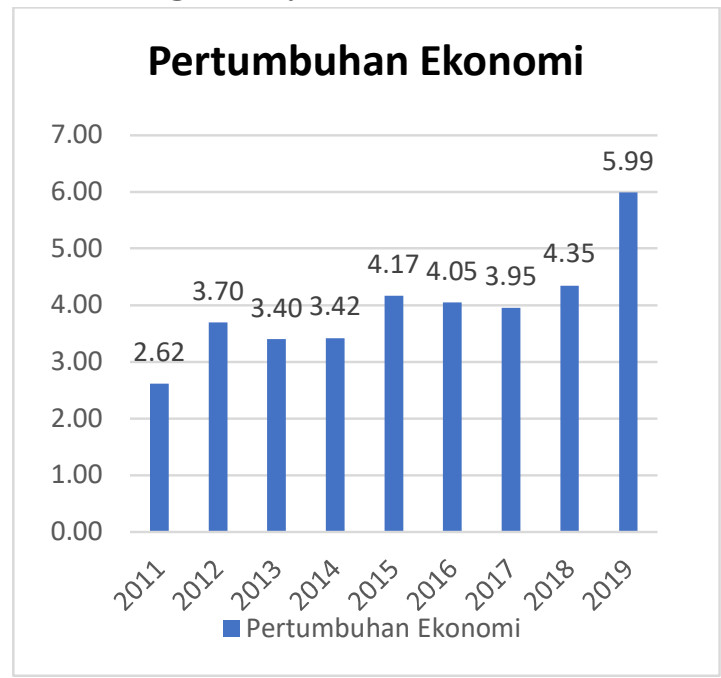

Sumber : BPS Kabupaten Nagan Raya 2020

Berdasarkan gambar di atas dapat dilihat kondisi pertumbuhan ekonomi di Kabupaten Nagan Raya selama kurun waktu tahun 2011-2019 secara garis besar mengalami peningkatan, meskipun sedikit berfluktuasi.

\section{Kondisi Penduduk Kabupaten Nagan Raya}

Kondisi pertumbuhan penduduk Aceh secara keseluruhan cenderung mengalami peningkatan jumlah setiap tahunnya sejak 2011-2019 (BPS Aceh, 2020) dan jika diamati peningkatan tersebut disumbang oleh pertumbuhan penduduk dari setiap kabupaten/kota yang ada di Aceh, salah satunya adalah Kabupaten Nagan Raya sebagai lokus penelitian ini. Pertumbuhan penduduk penting diperhatikan agar jumlah penduduk, luas wilayah dan pertumbuhan ekonomi dapat seimbang. Pertumbuhan penduduk Kabupaten Nagan Raya dapat dilihat dalam tabel berikut:

\section{Tabel III}

Jumlah Penduduk Kabupaten Nagan

Raya

\begin{tabular}{|c|c|}
\hline Tahun & $\begin{array}{c}\text { Jumlah Penduduk } \\
\text { (jiwa) }\end{array}$ \\
\hline 2010 & 140.295 \\
2011 & 143.718 \\
2012 & 146.386 \\
2013 & 149.397 \\
2014 & 152.352 \\
2015 & 155.070 \\
2016 & 158.223 \\
2017 & 161.329 \\
2018 & 164.483 \\
2019 & 167.294 \\
\hline
\end{tabular}

Sumber : BPS Kabupaten Nagan Raya 2020

Tabel di atas dapat dijelaskan bahwa penduduk Kabupaten Nagan Raya mengalami peningkatan jumlah setiap tahunnya. Jika dilihat dari kepadatan penduduk, Kabupaten Nagan Raya menempati urutan ke-14 terpadat dari 23 kabupaten/kota yang ada di Aceh. Pertumbuhan penduduk memberi pengaruh yang signifikan terhadap keadaan ekonomi, kuantitas atau jumlah penduduk yang tidak dibarengi dengan kualitas SDM maka akan meningkatkan angka pengangguran sebagai salah satu indikator tingkat kemiskinan, demikian juga dengan kekurangan jumlah penduduk akan mempengaruhi kelangkaan tenaga kerja untuk menyumbang pendapatan suatu daerah.

\section{Kondisi Tingkat Kemiskinan Kabupaten Nagan Raya \\ Kemiskinan merupakan persoalan yang} tidak boleh dianggap ringan karena dapat menempatkan suatu negara dalam situasi krisis ekonomi yang sekaligus menciptakan permasalahan lainnya seperti kesulitan akses pendidikan, carut-marut tatanan kehidupan sosial masyarakat, politik uang sampai pada mafia hukum. Maka, seyogyanya tingkat 
kemiskinan suatu daerah ditekan sampai pada angka yang serendah-rendahnya.

BPS Nagan Raya (2020) menyampaikan laporan tahunnanya terkait angka kemiskinan menunjukan penurunan dari 23,38 pada tahun 2011 menjadi 17,97 pada tahun 2020, namun demikian masih lebih tinggi dari angkan rata-rata yang direkomendasikan pemerintah provinsi yaitu 15,32. Kondisi penduduk miskin kabupaten Nagan Raya setiap tahunnya dapat diamati dalam gambar II berikut ini.

\section{Gambar II}

Persentase Penduduk Miskin Kabupaten Nagan Raya dan Provinsi Aceh

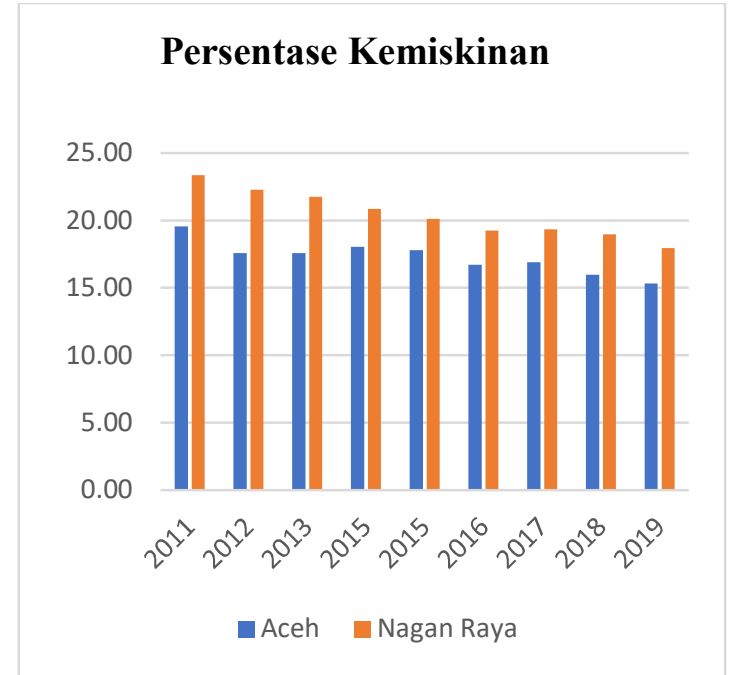

Sumber : BPS Kabupaten Nagan Raya 2020

Dari Gambar di atas dapat dilihat kondisi kemiskinan di Kabupaten Nagan selama kurun waktu tahun 2011-2019, yang dimana selama kurun waktu tersebut tingkat kemiskinan di Kabupaten Nagan Raya mengalami tren penurunan namun apabila kita bandingkan tingkat kemiskinan rata-rata Provinsi Aceh, angka kemiskinan di Nagan Raya masih tergolong tinggi karena masih berada di atas angka kemiskinan Provinsi Aceh.

\section{Uji Asumsi Klasik}

Sebelum dilakukan interpretasi terhadap hasil regresi dari model yang digunakan, maka terlebih dahulu dilakukan pengujian asumsi klasik agar model prediksi yang dihasilakn bersifat BLUE (Best Linier Unbiased Estimation). Pada model regresi linier berganda, asumsi klasik yang digunakna antara lain, normalitas, multikolinearitas, Heteroskedastisitas dan uji autolekasi. Berikut ini hasil pengujian dari asumsi klasik tersebut:

\section{Uji Normalitas}

Uji normalitas digunakan untuk menguji apakah dalam model regresi, variable bebas dan variable terikat mempunyai distribusi normal atau tidak. Model regresi yang baik adalah yang mempunyai distribusi normal atau mendekati normal.

Tabel IV Hasil Uji Normalitas

\begin{tabular}{llr}
\hline & & $\begin{array}{c}\text { Unstandardized } \\
\text { Residual }\end{array}$ \\
\hline $\mathrm{N}$ & & 10 \\
\hline Normal & Mean & .0000000 \\
\cline { 2 - 3 } Parameters & Std. Deviation & .01381974 \\
\hline Most Extreme & Absolute & .177 \\
\cline { 2 - 3 } Differences & Positive & .141 \\
\cline { 2 - 3 } & Negative & -.177 \\
\hline Test Statistic & & .177 \\
\hline Asymp. Sig. (2-tailed) & $.200^{\mathrm{c}, \mathrm{d}}$ \\
\hline
\end{tabular}

Sumber : output SPSS (diolah 2020)

Berdasarkan tabel output tersebut, diketahui bahwa nialai asymp.sig (2-tailed) sebesar 0,200 lebih besar dari 0,05. Maka sesuai dengan dasar keputusan Kolmogorovsmornov, dapat disimpulkan data terdistribusi secara normal. Dengan demikian, asumsi atau persyaratan normalitas dalam model regresi sudah terpenuhi. 


\section{Uji Heteroskedastisitas}

Deteksi Heteroskedastisitas dilakukan untuk mengetahui apakah semua disturbance term memiliki varians yang sama atau tidak (Gujarati, 2003). Jika variance dari nilai residual satu pengamatan ke pengamatan lain bersifat tetap, maka disebut homoskedastisitas, tetapi apabila variance dari nilai residual satu pengamatan ke pengamatan lain berbeda maka disebut heteroskedastisitas. Model regresi yang baik adalah yang tidak terjadi gejala heteroskedastisitas.

\section{Tabel V}

Hasil Uji Heteroskedastisitas

\begin{tabular}{lr}
\hline \multicolumn{1}{c}{ Model } & \multicolumn{1}{c}{ Sig } \\
\hline (Constant) & .546 \\
\hline Ln_Penduduk & .309 \\
\hline Ln_PDRB & .342 \\
\hline
\end{tabular}

a. Dependent Variable: Abs_RES

Sumber : output SPSS (diolah 2020)

Berdasarkan tabel $\mathrm{V}$ di atas, diketahui nilai signifikansi (Sig) untuk variable Jumlah Penduduk (X1) adalah 0,309 dan nilai signifikansi (sig) untuk variable PDRB (X2) adalah 0,342. Karena nilai signifikansi lebih besar dari 0,05 maka sesuai dengan dasar pengambilan keputusan dalam uji glejser, dapat disimpukan bahwa tidak terjadi gejala heteroskedastisitas dalam model regresi.

\section{Uji Multikolinearitas}

Uji multikolinearitas bertujuan untuk menguji apakah apakah model regresi ditemukan adanya kolerasi (hubungan kuat) antar variable. Model regresi yang baik seharusnya tidak terjadi kolerasi antara variable bebas dan tidak terjadi gejala multikolinearitas

\section{Tabel VI}

\section{Hasil Uji Multikolinearitas}

\begin{tabular}{|c|c|c|c|c|}
\hline \multirow{2}{*}{\multicolumn{2}{|c|}{ Model }} & \multicolumn{3}{|c|}{ Collinearity Statistics } \\
\hline & & B & Tolerance & VIF \\
\hline 1 & (Constant) & 18.867 & & \\
\hline & Ln_Penduduk & -.318 & .225 & 3.627 \\
\hline & Ln_PDRB & -.161 & .225 & 3.627 \\
\hline & ependent Var & le: $\operatorname{Ln} 1$ & Kemiskinan & \\
\hline
\end{tabular}

Dari tabel di atas dapat dilihat hasil dari pengujian multikolinearitas. Dalam pengambilan keputusan untuk uji multikolinearitas dapat dilakukan dengan cara melihat nilai tolerance dan VIF. Berdasarkan output hasil pengujian pada table diatas diketahui nilai collinearity telerance untuk variable jumlah penduduk (X1) dan PDRB (X2) adalah sebesar 0,225 lebih besar dari 0,10 . Sementara nilai VIF untuk kedua variable bebas tersebut yaitu 3,627 $<10,00$, maka jika mengacu pada dasar pengambilan keputusan untuk uji multikolinearitas dapat disimpulkan tidak terjadi gejala multikolinearitas pada model regresi.

\section{Uji Autokolerasi}

Uji autokorelasi digunakan untuk melihat apakah ada atau tiidaknya penyimpangan asumsi klasik autokolerasi yaitu kolerasi yang terjadi anatar residual pada suatu pengamatan dengan pengamatan lain pada model regres. Model regresi yang baik adalah model regresi yang bebas autokolerasi.

Tabel VII

\section{Hasil Uji Autokolerasi}

\begin{tabular}{|c|c|c|c|}
\hline Model & $\begin{array}{c}\mathbf{R} \\
\text { Square }\end{array}$ & $\begin{array}{l}\text { Std. Error } \\
\text { of the } \\
\text { Estimate }\end{array}$ & Durbin-Watson \\
\hline 1 & .879 & .01567 & 1.888 \\
\hline $\begin{array}{ll}\text { a. } & \text { Pr } \\
& \mathrm{Ln} \\
\text { b. } & \mathrm{De}\end{array}$ & $\begin{array}{l}\text { dictors: (C } \\
\text { Pendudul } \\
\text { pendent V }\end{array}$ & $\begin{array}{l}\text { onstant), Ln } \\
\text { uriable: Ln_K }\end{array}$ & $\begin{array}{l}\text { PDRB, } \\
\text { emiskinan }\end{array}$ \\
\hline
\end{tabular}


Dari hasil output di atas diketahui nilai Durbin-Watson sebesar 1,888, kemudian selanjutnya di bandingkan dengan nilai table Durbit-watson pada signifikan 5\% maka diketahui nilainya adalah 1.6413 lebih besar dari batas atas (dU). Berdasarkan hal tersebut maka dapat disimpulkan bahwa tidak terdapat masalah atau gejalan autokolerasi.

\section{Hasil Analisis Data}

Untuk melihat pengaruh dari Jumlah Penduduk dan PDRB Terhadap tingkat kemiskinan maka dilakukan analisis regresi linier berganda dengan menggunakan Program SPSS versi 24. Dari hasil perhitungan yang telah dilakukan, maka diperoleh hasil sebagai berikut :

Tabel VIII

\section{Hasil Regresi Linier Berganda}

\begin{tabular}{|l|c|r|r|c|c|}
\hline \multirow{3}{*}{ Variabel } & \multicolumn{2}{|c|}{$\begin{array}{l}\text { Unstandardized } \\
\text { Coefficients }\end{array}$} & $\begin{array}{c}\text { Standard } \\
\text { ized } \\
\text { Coefficie } \\
\text { nts }\end{array}$ & T & Sig \\
\cline { 2 - 6 } & B & $\begin{array}{c}\text { Std. } \\
\text { Error }\end{array}$ & Beta & & \\
\hline Konstanta & 18.867 & 2.739 & & 6.888 & .000 \\
Penduduk & -.3118 & .859 & -.470 & -.370 & .722 \\
PDRB & -.161 & .434 & -.469 & -.370 & .723 \\
\hline
\end{tabular}

Sumber : output SPSS (diolah 2020)

Berdasarkan tabel hasil regresi tersebut, maka diperoleh persamaan regresi sebagai berikut :

$$
\operatorname{LnY}=18.867-0,3188-0,161+e
$$

Dari persamaan tersebut dapat dijelaskan bahwa :

1. Koefisien regresi untuk variable Jumlah Penduduk sebesar -0,3118, hal ini mengandung arti bahwa apabila jumlah penduduk mengalami peningkatan sebesar 1 persen maka maka tingkat kemiskinan di Kabupaten Nagan Raya menurun sebesar 0,3118 persen.
2. Koefisien regresi untuk variable PDRB sebessar 0,161, hal ini berarti bahwa apabila PDRB meningkkat sebesar 1 persen makan tingkat kemiskinan di Kabupaten Nagan Raya mennurun sebesar 0,161 persen.

Tabel IX Hasil Regresi Uji F

\begin{tabular}{|l|r|r|r|c|c|}
\hline \multicolumn{1}{|c|}{ Model } & $\begin{array}{r}\text { Sum of } \\
\text { Squares }\end{array}$ & Df & $\begin{array}{c}\text { Mean } \\
\text { Square }\end{array}$ & F & Sig. \\
\hline Regression & .013 & 2 & .006 & 25.527 & .001 \\
Residual & .002 & 7 & .000 & & \\
Total & .014 & 9 & & & \\
\hline
\end{tabular}

Sumber : output SPSS (diolah 2020)

Pada dasarnya uji F dilakukan untuk melihat apakah semua variabel independen yang dimasukan dalam model mempunya pengaruh secara bersama-sama (simultan) terhadap variable dependen.

Dari tabel hasil regresi tersebut dapat dijelaskan bahwa pengaruh jumlah penduduk dan PDRB terhadap Tingkat kemiskinan di Kabupaten Nagan Raya tahun 2010-2019 Sebagaimana sajikan pada Tabel 6, nilai F-hitung sebesar 25,527 atau lebih tinggi dibandingkan dengan nilai Ftabel yang hanya sebesar 4,74. Dengan demikian dapat disimpulkan bawah kedua variabel bebas yang dimasukkan dalam model ini yakni PDRB dan jumlah penduduk secara bersama-sama (simultan) berpengaruh nyata terhadap tingkat kemiskinan di Kabupaten Nagan Raya.

Selain melakukan uji $\mathrm{F}$, juga dilakukan uji statistic $t$, yang bertujuan untuk melihat seberapa jauh pengaruh masing-masing variabel independen secara individual dalam menerangkan variasi variabel dependen. Berikut ini hasil pengujian statistik t. 
Tabel X

Hasil Uji t-statistik

\begin{tabular}{|l|r|r|}
\hline \multicolumn{1}{|c|}{ Variabel } & T-hitung & $\begin{array}{c}\text { t-tabel } \\
(\boldsymbol{\alpha}=\mathbf{5 \%})\end{array}$ \\
\hline Penduduk & -.370 & 1.895 \\
PDRB & -.370 & 1.895 \\
\hline
\end{tabular}

Sumber : output SPSS (diolah 2020)

Berdasarkan pengujian tersebut, maka dapat dijelaskan bahwa secara parsial variabel Jumlah penduduk dan variabel PDRB tidak memberikan pengaruh yang signifikan terhadap variabel tingkat kemiskinan di Kabupaten Nagan Raya, hal ini dapat di lihat dari nilai Thitung pada variable tersebut lebih kecil dari nilai Ttabel.

Selain uji $t$ dan $F$, selanjutnya dilakukan analisis koefisien determinasi untuk mengetahui tingkat kerentanan serta arah hubungaan antara PDRB dan jumlah penduduk terhadap tingkat kemiskinan di Kabupaten Nagan Raya. Untuk melihat nilai koefisien determinasi dapat dilihat pada tebel berikut ini:

Tabel XI

Koefisien Determinasi $\left(\mathbf{R}^{2}\right)$

\begin{tabular}{|c|c|c|c|}
\hline $\mathbf{R}$ & $\begin{array}{c}\text { R } \\
\text { Square }\end{array}$ & $\begin{array}{c}\text { Adjusted } \\
\text { R Square }\end{array}$ & $\begin{array}{c}\text { Std. Error } \\
\text { of the } \\
\text { Estimate }\end{array}$ \\
\hline $.938^{\mathrm{a}}$ & .879 & .845 & .01567 \\
\hline
\end{tabular}

Sumber : output SPSS (diolah 2020)

Dari tabel tersebut diketahui bahwa nilai koefisien determinasi sebesar 0,879 , hal ini mengandung arti bahwa tingkat kemiskinan di Kabupaten Nagan Raya sebesar 87,9\% dipengaruhi oleh Jumlah Penduduk dan PDRB, sedangkan sisanya $12,1 \%$ dipengaruhi oleh variable lain diluar model penelitian ini.

\section{E. KESIMPULAN DAN SARAN}

\section{Kesimpulan}

Berdasarkan hasil penelitian yang telah dilakukan, maka dapat diambil kesimpulan sebagai berikut:

a. Secara simultan jumlah penduduk dan PDRB berpengaruh terhadap kemiskinan di Kabupaten Nagan Raya, hal ini dapat dilihat dari nilai $F_{\text {hitung }}$ sebesar 25,527 lebih besar dibandingkan dengan nilai $F_{\text {tabel }}$ yang hanya sebesar 4,47.

b. Secara parsial, variabel jumlah penduduk dan PDRB tidak memberikan pengaruh yang signifikan terhadap kemiskinan di Kabupaten Nagan Raya, hal ini dapat dilihat dari nilai $\mathrm{T}_{\text {hitung }}$ kedua variabel tersebut lebih kecil dari nilai $\mathrm{T}_{\text {tabel. }}$.

c. Dari hasil analisis koefisien determinasi maka dapat disimpukan bahwa variable Jumlah penduduk dan PDRB memiliki berpengaruh sebesar $97,9 \%$ terhadap Kemiskinan dan sisanya $12,1 \%$ di pengaruhi oleh variabel lain diluar penelitian ini.

\section{Saran}

Berdasarkan penelitian yang telah dilakukan, maka penulis memeberikan beberapa saran, yaitu sebagai berikut :

a. Mayoritas penduduk nagan raya adalah bekerja di sector pertanian, untuk itu di harapkan kepada pemerintah Kabupaten Nagan Raya, untuk terus berperan aktif dalam meningkatkan produktivitas di bidang pertanian tersebut sehingga dapat berkontribusi lebih baik dalam pertumbuhan ekonomi.

b. Perlunya kebijakan yang lebih baik bagi Pemerintah Kabupaten Nagan Raya untuk lebih memprioritaskan dalam pengetasan kemiskinan, seperti halnya meningkatkan jumlah lapangan kerja, meningkatkan kualitas pendidikan bagi warga sehingga tercipta kualitas Sumber 
Daya Manusia (SDM) yang lebih baik dan mampu bersaing dalam dunia kerja.

\section{DAFTAR PUSTAKA}

Adioetomo, Sri Moertaningsih dan Omas Bulan Samosir. 2010. Dasar-Dasar Demografi. Jakarta: Salemba Empat.

Badan Perencanaan Pembangunan Nasional (Bappenas). 2004. Stategi Nasional Penanggulangan Kemiskinan. Jakarta: Bappenas.

Novri Silastri. 2017. Pengaruh Jumlah Penduduk dan Pendapatan Domestik Regional bruto (PDRB) Terhadap Kemiskinan di Kabupaten Kuatan Singingi. JOM Fekom Vol 4 No. 1.

Reza Atta Biurobbi. 2013. Faktor-faktor yang memepengaruhi kemiskinan di
Kecamatan Jekulo dan Mojebo Kabupaten Kudus. EDAJ 2 (4)

Saberan, H. 2002. Produk Domestik Regional Bruto. Jakarta: Rajawali.

Sukirno, Sadono. 2005. Pengantar Teori Ekonomi Makro. Jakarta : Predana Media Group.

Tambunan, Tulus. 2003. Perekonomian Indonesia beberapa Masalah Penting. Jakarta: Ghalia Indonesia

https://naganrayakab.bps.go.id/subject/12/ke pendudukan.html\#subjekViewTab1, diakses tanggal 25 April 2020

https://naganrayakab.bps.go.id/subject/23/ke miskinan.html\#subjekViewTab1, diakses tanggal 25 April 2020

https://naganrayakab.bps.go.id/subject/52/pro duk-domestik-regionalbruto.html.subjekViewTab1, diakses tanggal 25 April 2020. 